\title{
Teacher and Learner Views on Effective English Teaching in the Thai Context: The Case of Engineering Students
}

\author{
Mantana Meksophawannagul ${ }^{1}$ \\ ${ }^{1}$ College of Industrial Technology, King Mongkut's University of Technology North Bangkok, Bangkok, \\ Thailand \\ Correspondence: Mantana Meksophawannagul, College of Industrial Teachnology, King Mongkut's University \\ of Technology North Bangkok, Bangkok, Thailand. Tel: 66-8-1441-1599. E-mail: airykmutnb@gmail.com
}

Received: July 20, 2015 Accepted: October 10, 2015 Online Published: October 11, 2015

doi:10.5539/elt.v8n11p99 URL: http://dx.doi.org/10.5539/elt.v8n11p99

\begin{abstract}
This study aimed at investigating the characteristics of effective English teachers and students as perceived by 35 teachers and 613 students, as well as according to the surveys regarding the English-teaching problems in Thailand. The instruments included two questionnaires on the characteristics of effective teachers and students as perceived by teachers and students, based on five categories: rapport, delivery, fairness, knowledge and creditability, organization and preparation. The questionnaire responses were analyzed both quantitatively and qualitatively.

The quantitative data revealed that for the teachers the most important attribute was organization and preparation attributes such as teaching preparation and the use of effective teaching methodology. The qualitative data revealed that the rapport items were important, especially that the teacher should be patient, not insult the students, and give clear advice. However, the students gave more weight to such rapport items as, for example, the teacher having a positive attitude toward to the students and being helpful, generous and caring about them. The qualitative data also revealed that well-prepared lessons and providing fun activities were mostly required for effective teachers. English teaching problems involve four aspects: teachers, learners, English learning content, and other factors. Discussion and the recommendations of the study are included.
\end{abstract}

Keywords: rapport, delivery, fairness, knowledge and creditability, organization and preparation, English teaching problems, attributes, and characteristics

\section{Introduction}

In Thailand, English is widely recognized as an important foreign language both in academic and occupational fields (Foley, 2005). However, many studies have indicated very low language proficiency of Thai students (Bunnag, 2005a, 2005b cited in Khamkhien, 2010; EF English Proficiency Index, 2012 cited in Phonthongsunan, 2014; ONET-reports, 2012-2014).

The scores on the two standardized tests, the TOEFL and TOEIC, officially indicated that Thai test takers' scores were significantly low (Bolton, 2008; Bunnag, 2005a, 2005b cited in Khamkhien, 2010). Moreover, Thailand came in at $53^{\text {rd }}$, the world's second-lowest rank, with an average score of 43.36 , according to the Educational First English Proficiency Index (EF English Proficiency Index, 2012 cited in Phonthongsunan, 2014). Thailand's English average scores (2012-2014) for the O-NET (Ordinary National Educational Test) were unsatisfactory; for example, 430,000 upper-secondary school students scored 22.12, 25.35, and 23.44, (out of 100) (O-NET reports, 2012-2014).

Without any doubt, effective English teachers have a great influence on students' achievement (Murray, 1991; Prabhu, 1990; Phothomsunan, 2014). An effective teacher creates an environment that enhances deep learning outcomes (Ramsden, 1992). The quality of effective teachers can be categorized in many ways depending on the researchers' interests. Many studies have categorized the attributes of effective teachers, for example, Babai and Sadeghi (2009), Faranda and Clarke (2004), Lowman (1997), Park and Lee (2006), and Wichadee (2010).

Babai and Sadeghi (2009) proposed that the key elements of effective language teachers include knowledge of 
the language, and pedagogy and the teacher's personality. Faranda and Clarke (2004) categorized effective teachers in terms of five attributes: rapport, delivery, fairness, knowledge and credibility, and organization and preparation. Rapport refers to the characteristics of teachers that take responsibility for their students and develop a good classroom atmosphere. Delivery is generally the discipline of providing useful content of instruction and teaching methodology. Fairness refers to the teachers' impartiality in the classroom interaction and the grading and curriculum frame. Knowledge and creditability refer to the teachers' competent and experiences in their subject area. Organization and preparation refer to all of the disciplines (i.e. course syllabus, learning objectives and goals, supplemental materials) that the learners want from teachers. Lowman (1997) proposed two distinct dimensions of effective teaching; namely, the instructor's ability to stimulate intellectual excitement and use of psychology in a classroom. Park and Lee (2006) suggested three elements, namely, English proficiency, pedagogical knowledge, and socio-affective skills; while Wichadee (2010) suggested four elements, namely English proficiency, pedagogical knowledge, organization and communication skills, and socio-affective skills.

Studies on the characteristics of effective language teachers have been carried out in many countries, for example, Turkey (Ghamsemi and Hashemi, 2011), Iran (Babai and Sadeghi, 2009), Australia (Ramsden, 2003), Asia (Barnes and Lock, 2010, 2013; Chen and Lin, 2009; Faranda and Clarke, 2004; Park and Lee, 2006; Xuerong, 2012), and Thailand (Chen, 2012; Wichadee, 2010).

Faranda and Clarke (2004) found that, based on the five attributes of effective teachers (i.e. rapport, delivery, fairness, knowledge and credibility, and organization and preparation), Korean university students viewed rapport and delivery as the most important characteristics of an EFL teacher. A study by Chen and Lin (2009) concluded that instructional competence, personality, and the teacher-student relationship were considered the key attributes of effective EFL teachers, while Wichadee (2010) found that organization and communication skills were important from the students' viewpoint.

Regarding the case of Thailand, Chen (2012) examined the favorable and unfavorable characteristics of EFL teachers and found that the sixty respondents that were undergraduate students at Vongchavalitkul University really cared about the EFL teachers' personality and how the teachers behaved toward them. They believed that an effective teacher should be kind, friendly, and understand the students. Moreover, the students expected a teacher to have the knowledge and ability necessary to deliver the content in a meaningful way.

Thus, it is believed that the teachers' characteristics have a strong influence on the learning process and products (Murray, 1991; Prabhu, 1990), although, in the Thai context, only one study, that by Phothomgsunan (2014), suggested a correlation between the students' achievement and the attributes of EFL teachers.

This study aimed at investigating both the teachers' and learners' views of the key attributes of effective English teachers, and examined the favorable characteristics of language learners as perceived by EFL teachers and learners. Although there are many studies on the characteristics of good language learners (Brown, 2000; Erman and Oxford, 1995; Gardner and MacIntyre, 1992; O’Malley and Chamot, 1990; Oxford, 1989, 1990;; Skehan, 1989; Young and Oxford, 1997), the research on effective EFL learners in the Thai context is very sparse, especially studies on engineering students. This study investigated the main obstacles to English teaching and learning in Thailand as well.

\section{Research Questions}

This study attempts to answer the following questions:

1) What are the attributes of effective English language teachers as perceived by teachers and students?

2) What are the attributes of effective English language learners as perceived by teachers and students?

3) What are the main causes obstructing English teaching and learning in the Thai context as perceived by teachers and students?

\section{Research Methodology}

\subsection{Participant}

The participants of this study were selected using the convenience sample method. They were divided into two groups: EFL teachers and EFL learners. Thai was the first language for all of the participants. 


\subsection{Setting}

The researcher contacted EFL teachers that were teaching at the university level. They were asked to complete an online questionnaire, which was delivered to them from June to September, 2014. Some of the teachers and students helped to share the online questionnaire link with their friends as well. The questionnaire was in Thai and took about 20-30 minutes to complete.

\subsection{Instrument}

Two online questionnaires (i.e. one was for EFL teachers and the other for EFL learners) were used. Both questionnaires were developed by the researcher to suit the Thai context based on related studies on the characteristics of effective EFL teachers and learners. The questionnaires were delivered online to three experts in order to validate their quality. After the researcher reviewed the questionnaires according to the experts' comments and suggestions, they were re-submitted to the experts.

\subsubsection{Questionnaire on the Quality of Effective English Teachers and Learners as Perceived by Teachers}

The questionnaire consisted of three parts. In the first part, the teachers were asked to provide general information (i.e. age, gender, level of education, and opinion on using technology in the language classroom). The second part included 30 attributes of effective English language teachers placed on a five-point Likert scale with additional open-ended questions. The 30 attributes were listed with option to rate them on a scale from 1 (not important at all) to 5 (very important). All of the attribute items were adapted from the concept proposed by Faranda and Clarke 2004 (i.e. five attribute categories: rapport, delivery, fairness, knowledge and credibility, and organization and preparation). Extra opinions on effective teachers could be given in an open-ended format. Problems of English teaching were also asked in the open-ended format. The last part included 14 attributes of good language learners placed again on a five-point Likert scale and with additional open-ended fomat. The 14 attributes were adapted from the studies on how to be good language learners (Norton and Toohey, 2001; Reid, 1987; Rubin and Thompson cited in Nunan 1999; Ushida, 2005) and on the interviews with three native Thai teachers that had taught English for at least 5 years, with the option to rate each item on a scale from 1 (not important at all) to 5 (very important). The teachers were asked to share their positive and negative experiences in teaching in an open-ended format as well.

4.3.2 Questionnaire on the Quality of Effective English Language Teachers and Learners as Perceived by Learners

This questionnaire comprised three parts. In the first part, the students were asked to provide general information (i.e. gender, years of studying English) as well as to rank their language proficiency (i.e. reading, speaking, listening, writing) from 1 (expert or competent) to 4 (not competent). Part two was similar to the second part of the questionnaire for the teachers above, excluding the part on problems of teaching. In the last part, the learners' opinions on effective EFL learners consisted of 14 items and the students were asked to rank the top-three obstacles to their language learning. It should be noted that the list of obstacles to language learning were synthesized from the studies of Biyaeam (1997), Dhanasobhon (2006), Kaewmorakot (2005), Noom-ura (2013), ONEC(2003), Pande (2013), and Silapasatham (2007). It consisted of ten items and an open-ended format. The students' opinions concerning their contentment with learning English with native Thai and native English speakers and the reasons for those opinions were requested in this part as well.

\subsection{Data Analysis}

The attributes of effective EFL teachers and EFL learners were analyzed using descriptive statistics. The arithmetic mean was calculated using the SPSS 17.0 computer program. The open-ended information was grouped and qualitatively analyzed.

\section{Results of the Study}

General information: In the present study there were 35 university English language teachers, of whom 5 (14\%) were male and $30(86 \%)$ female. Nineteen teachers had a doctoral degree and sixteen a master degree. These teachers (97\%) believed that teachers should have knowledge of technology in order to teach a target language comfortably.

Six hundred and thirteen engineering major students were the samples of this study. Of these, 468 (76\%) were male and $145(24 \%)$ female. The average age was 22 years and the average years of studying English was 14.6. The results showed that the respondents ranked reading skills (i.e. 504 out of 613 students $=82 \%$ ) as the highest 
language competency, followed by listening (i.e. 287 out of 613 students $=47 \%$ ), speaking (i.e. 333 out of 613 students $=54 \%$ ), and writing (i.e. 402 out of 613 students $=66 \%$ ).

\subsection{The Attributes of Effective English Language Teachers as Perceived by Teachers and Students}

The quantitatively and qualitative analyses consisted of two parts: teachers' views and students' views.

The arithmetic means for effective English language teachers as perceived by both teachers and students are presented in Table 1. Table 2 illustrates the overall ranking of attributes grouped into five categories based on Faranda and Clarke (2004) and as perceived by teachers and students. Tables 3-7 show the mean scores and standard deviations for each category (i.e. rapport, delivery, fairness, knowledge and credibility, and organization and preparation).

\subsubsection{Quantitative Data- Teachers' Views}

According to Table 1, the attribute of effective EFL teachers with the highest means was "to be fair" (i.e. item 20: $M=4.80$ ), followed by the "ability to use relevant real world example in the lessons" (i.e. item 9: $M=4.77$ ). The

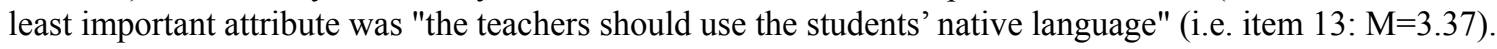

Among the five categories of effective teachers, the mean scores were arranged in order of importance as follows: organization and preparation $(\mathrm{M}=4.66)$, rapport $(\mathrm{M}=4.52)$, fairness $(\mathrm{M}=4.50)$, knowledge and credibility $(\mathrm{M}=4.43)$, and delivery $(\mathrm{M}=4.21)$ (Table 2). When investigating the attributes in each category, it can be concluded that effective teachers should have the following attributes:

- According to Table 3, being punctual and patient, as well as giving clear advice and not insulting the students were the top three important "rapport" items where the mean sores of three items were 4.74.

- As shown in Table 4, the most important "delivery" item was the teachers' ability to use relevant real world examples in the lessons $(\mathrm{M}=4.77)$.

- $\quad$ Tables 5 showed that being fair was the most important "fairness" item $(\mathrm{M}=4.80)$.

- Clearly understanding the course content, objectives, and evaluation received the highest mean for the "knowledge and credibility" items (M=4.74) (Table 6).

- As shown in Table 7, well prepared lessons were the most important "organization and preparation" items $(\mathrm{M}=4.74)$.

\subsubsection{Quantitative Data -Students'views}

According to Table 1, the important characteristic of effective teachers was that the teachers should have positive attitudes towards the students and be helpful to them in and outside the classroom (i.e. item 28: $M=4.43$ ). Being open to criticism (i.e. item 30: $\mathrm{M}=4.39$ ) was nominated as the second most important, while assigning homework to review the lessons was the least important attributes $(\mathrm{M}=3.91)$.

As clearly shown in Table 2, the students viewed that rapport was the most important category $(\mathrm{M}=4.31)$, followed by organization and preparation $(\mathrm{M}=4.23)$, delivery $(\mathrm{M}=4.17)$, fairness $(\mathrm{M}=4.15)$, and knowledge and credibility ( $\mathrm{M}=4.15)$.

When investigating the attributes in each category, it can be concluded that effective teachers should have the following attributes:

- According to Table 3, having positive attitudes towards students and being helpful were the most important "rapport" items $(\mathrm{M}=4.43)$.

- $\quad$ Regarding the "delivery" items in Table 4, the most important attributes were providing fun activities, being upbeat, and having a sense of humor $(\mathrm{M}=4.38)$.

- Sticking to rules and regulations and enhancing the students' morality were positioned at the highest mean for the "fairness" items (M=4.32) (Table 5).

- $\quad$ Regarding the "knowledge and credibility" items in Table 6, the students believed that teachers should have a high level of English proficiency (M=4.24).

- As shown in Table 7, well-prepared lessons were the most important attribute for the "organization and preparation" items $(\mathrm{M}=4.26)$. 
Table 1. Mean scores and standard deviation of the attributes of effective English language teachers as perceived by the EFL teachers and EFL students

\begin{tabular}{|c|c|c|c|c|c|c|c|}
\hline \multirow[t]{2}{*}{ No. } & \multirow[t]{2}{*}{ Statements } & \multicolumn{3}{|c|}{ Teachers } & \multicolumn{3}{|c|}{ Students } \\
\hline & & Mean & SD & Rank & Mean & SD & Rank \\
\hline \multicolumn{8}{|c|}{ Effective teachers should } \\
\hline 1 & Prepare the lessons well & 4.74 & .443 & 3 & 4.26 & .593 & 12 \\
\hline 2 & 1. Manage class time effectively and systematically & 4.57 & .558 & 8 & 4.19 & .647 & 14 \\
\hline 3 & $\begin{array}{l}\text { 2. Clearly provide a comprehensive syllabus with } \\
\text { course objectives, methodology, and course evaluation }\end{array}$ & 4.60 & .497 & 7 & 4.18 & .674 & 15 \\
\hline 4 & $\begin{array}{l}\text { 3. Clearly understand course content, course objectives, } \\
\text { and course evaluation }\end{array}$ & 4.74 & .443 & 3 & 4.15 & .692 & 17 \\
\hline 5 & $\begin{array}{l}\text { 4. Use a variety of teaching aids and technology in class } \\
\text { such as audio/visual media }\end{array}$ & 4.54 & .505 & 9 & 4.20 & .716 & 13 \\
\hline 6 & 5. Be able to explain English grammatical rules clearly & 4.43 & .739 & 11 & 4.12 & .803 & 19 \\
\hline 7 & 6. Have English pronunciation close to natives & 4.11 & .832 & 16 & 4.12 & .776 & 19 \\
\hline 8 & $\begin{array}{l}\text { 7. Have high level of English proficiency (listening, } \\
\text { speaking, reading, and writing) }\end{array}$ & 4.43 & .608 & 11 & 4.24 & .750 & 12 \\
\hline 9 & Use relevant real world examples in the lessons & 4.77 & .426 & 2 & 4.30 & .695 & 8 \\
\hline 10 & Know information of the target language cultures & 4.40 & .604 & 12 & 4.07 & .730 & 21 \\
\hline 11 & $\begin{array}{l}\text { Be patient. Monitor and give clear advice for error } \\
\text { correction. Do not insult students when they make } \\
\text { mistakes. }\end{array}$ & 4.74 & .505 & 3 & 4.30 & .756 & 8 \\
\hline 12 & Use the target language as a medium of communication & 3.91 & .887 & 19 & 3.97 & .856 & 24 \\
\hline 13 & Use the students' native language only when necessary & 3.37 & .808 & 21 & 4.04 & .828 & 23 \\
\hline 14 & Be able to answer complex questions & 4.23 & .770 & 14 & 4.09 & .750 & 20 \\
\hline 15 & Provide interesting and meaningful activities & 4.51 & .612 & 10 & 4.19 & .709 & 14 \\
\hline 16 & $\begin{array}{l}\text { Induce students' motivation and interest. Help students } \\
\text { build up confidence }\end{array}$ & 4.71 & .572 & 4 & 4.26 & .758 & 11 \\
\hline 17 & Assign homework for reviewing the lessons & 4.09 & .658 & 17 & 3.91 & .833 & 25 \\
\hline 18 & Give students regular tests for reviewing the lessons & 4.26 & .611 & 13 & 4.05 & .762 & 22 \\
\hline 19 & Encourage group work and participation & 4.17 & .664 & 15 & 4.14 & .727 & 19 \\
\hline 20 & $\begin{array}{l}\text { Be fair (on giving feedback, grading, paying attention to } \\
\text { individual differences) }\end{array}$ & 4.80 & .406 & 1 & 4.29 & .708 & 9 \\
\hline 21 & Be punctual & 4.74 & .505 & 3 & 4.31 & .699 & 7 \\
\hline 22 & Give prompt feedback on assignments & 4.66 & .539 & 6 & 4.19 & .726 & 14 \\
\hline 23 & Have good personality or appearance & 4.03 & .618 & 18 & 4.16 & .732 & 16 \\
\hline 24 & Not discriminate students and treat them fairly & 4.69 & .530 & 5 & 4.36 & .708 & 4 \\
\hline 25 & Be flexible & 4.54 & .561 & 9 & 4.25 & .731 & 11 \\
\hline 26 & Listen to students, not lose temper easily, and be kin & 3.89 & .796 & 20 & 4.33 & .737 & 5 \\
\hline 27 & $\begin{array}{l}\text { Provide fun activities, entertain students in class, and make } \\
\text { difficult content easy. Be upbeat (full of hope, happiness } \\
\text { and good feelings) and have a sense of humor }\end{array}$ & 4.54 & .505 & 9 & 4.38 & .735 & 3 \\
\hline 28 & $\begin{array}{l}\text { Have positive attitudes toward students. Be helpful to } \\
\text { students in and outside the classroom }\end{array}$ & 4.69 & .471 & 5 & 4.43 & .640 & 1 \\
\hline 29 & $\begin{array}{l}\text { Stick to rules and regulations. Try to enhance the students' } \\
\text { morality. Build an awareness of wrong behavior and } \\
\text { cheating }\end{array}$ & 4.74 & .443 & 3 & 4.32 & .686 & 6 \\
\hline 30 & Be open to criticism & 4.69 & .471 & 5 & 4.39 & .700 & 2 \\
\hline
\end{tabular}


Table 2. Overall ranking of attributes by five categories (Faranda and Clarke, 2004) as perceived by the EFL teachers and EFL students

\begin{tabular}{lllllll}
\hline Category & \multicolumn{3}{c}{ Teachers } & \multicolumn{3}{c}{ Students } \\
\cline { 2 - 7 } & Mean & S.D. & Rank & Mean & S.D. & Rank \\
\hline 1. Rapport (i.e. items 11, 16, 21, 23, 24, 25, 26, 28, 30) & 4.52 & .372 & 2 & 4.31 & .448 & 1 \\
2. Delivery (i.e. items 9, 12, 13, 15, 19, 27) & 4.21 & .374 & 5 & 4.17 & .412 & 3 \\
3. Fairness (i.e. items 17, 18, 20, 22, 29) & 4.50 & .367 & 3 & 4.15 & .524 & 4 \\
4. Knowledge \& Credibility (i.e. items 3, 4, 5, 6, 7, 8, & 4.43 & .392 & 4 & 4.14 & .389 & 5 \\
10, 14) & & & & & & \\
5. Organization \& Preparation (i.e. items 1, 2) & 4.66 & .433 & 1 & 4.23 & .556 & 2 \\
\hline
\end{tabular}

Table 3. Mean scores and standard deviations for rapport items

\begin{tabular}{|c|c|c|c|c|c|c|c|}
\hline \multirow[t]{2}{*}{ No. } & \multirow[t]{2}{*}{ Statements } & \multicolumn{3}{|c|}{ Teachers } & \multicolumn{3}{|c|}{ Students } \\
\hline & & Mean & SD & Rank & Mean & SD & Rank \\
\hline \multicolumn{8}{|c|}{ Effective teachers should } \\
\hline 11 & $\begin{array}{l}\text { Be patient. Monitor and provide clear advice for error } \\
\text { correction. Not insult students when they make mistakes. }\end{array}$ & 4.74 & .505 & 1 & 4.30 & .756 & 6 \\
\hline 16 & $\begin{array}{l}\text { Encourage students motivation and interest. Help } \\
\text { students to build up confidence }\end{array}$ & 4.71 & .572 & 2 & 4.26 & .758 & 7 \\
\hline 21 & Be punctual & 4.74 & .505 & 1 & 4.31 & .699 & 5 \\
\hline 23 & Have good personality or appearance & 4.03 & .618 & 5 & 4.16 & .732 & 9 \\
\hline 24 & Not discriminate students and treat them fairly & 4.69 & .530 & 3 & 4.36 & .708 & 3 \\
\hline 25 & Be flexible & 4.54 & .561 & 4 & 4.25 & .731 & 8 \\
\hline 26 & Listen to students, not lose temper easily, and be kind & 3.89 & .796 & 6 & 4.33 & .737 & 4 \\
\hline 28 & $\begin{array}{l}\text { Have positive attitudes toward students. Be helpful to } \\
\text { students in and outside the classroom }\end{array}$ & 4.69 & .471 & 3 & 4.43 & .640 & 1 \\
\hline 30 & Be open to criticism & 4.69 & .471 & 2 & 4.39 & .700 & 2 \\
\hline
\end{tabular}

Table 4. Mean scores and standard deviations for delivery items

\begin{tabular}{llllllll}
\hline No. & Statements & \multicolumn{3}{l}{ Teachers } & \multicolumn{4}{l}{ Students } \\
\cline { 3 - 8 } & & Mean & SD & Rank & Mean & SD & Rank \\
\hline Effective teachers should & & & & & & \\
9 & Use relevant real world examples in the lessons & 4.77 & .426 & 1 & 4.30 & .695 & 2 \\
12 & Use target language as a medium of communication & 3.91 & .887 & 5 & 3.97 & .856 & 6 \\
13 & Use the students' native language only when necessary & 3.37 & .808 & 6 & 4.04 & .828 & 5 \\
15 & Provide interesting and meaningful activities & 4.51 & .612 & 3 & 4.19 & .709 & 3 \\
19 & Encourage group work and participation & 4.17 & .664 & 4 & 4.14 & .727 & 4 \\
27 & $\begin{array}{l}\text { Provide fun activities, entertain students in class, and } \\
\text { make difficult content easy. Be upbeat (full of hope, }\end{array}$ & 4.54 & .505 & 2 & 4.38 & .735 & 1 \\
& happiness and good feelings) and have a sense of humor
\end{tabular}


Table 5. Mean scores and standard deviations for fairness items

\begin{tabular}{|c|c|c|c|c|c|c|c|}
\hline \multirow[t]{2}{*}{ No. } & \multirow[t]{2}{*}{ Statements } & \multicolumn{3}{|c|}{ Teachers } & \multicolumn{3}{|c|}{ Students } \\
\hline & & Mean & SD & Rank & Mean & SD & Rank \\
\hline \multicolumn{8}{|c|}{ Effective teachers should } \\
\hline 17 & Assign homework for reviewing the lessons & 4.09 & .658 & 5 & 3.91 & .833 & 5 \\
\hline 18 & Give students regular tests for reviewing the lessons & 4.26 & .611 & 4 & 4.05 & .762 & 4 \\
\hline 20 & $\begin{array}{l}\text { Be fair (on giving feedback, grading, paying attention to } \\
\text { individual differences) }\end{array}$ & 4.80 & .406 & 1 & 4.29 & .708 & 2 \\
\hline 22 & Give prompt feedback on assignments & 4.66 & .539 & 3 & 4.19 & .726 & 3 \\
\hline 29 & $\begin{array}{l}\text { Stick to rules and regulations. Try to enhance the } \\
\text { students' morality. Build an awareness of wrong } \\
\text { behavior and cheating }\end{array}$ & 4.74 & .443 & 2 & 4.32 & .686 & 1 \\
\hline
\end{tabular}

Table 6. Mean scores and standard deviations for knowledge and credibility items

\begin{tabular}{|c|c|c|c|c|c|c|c|}
\hline \multirow[t]{2}{*}{ No. } & \multirow[t]{2}{*}{ Statements } & \multicolumn{3}{|c|}{ Teachers } & \multicolumn{3}{|c|}{ Students } \\
\hline & & Mean & SD & Rank & Mean & SD & Rank \\
\hline \multicolumn{8}{|c|}{ Effective teachers should } \\
\hline 3 & $\begin{array}{l}\text { 8. Clearly provide a comprehensive syllabus with } \\
\text { course objectives, methodology, and course } \\
\text { evaluation }\end{array}$ & 4.60 & .497 & 2 & 4.18 & 674 & 3 \\
\hline 4 & $\begin{array}{l}\text { 9. Clearly understand course content, course } \\
\text { objectives, and course evaluation }\end{array}$ & 4.74 & .443 & 1 & 4.15 & 692 & 4 \\
\hline 5 & $\begin{array}{l}\text { 10. Use a variety of teaching aids and technology in } \\
\text { class such as audio/visual media }\end{array}$ & 4.54 & .505 & 3 & 4.20 & .716 & 2 \\
\hline 6 & $\begin{array}{l}\text { 11. Be able to explain English grammatical rules } \\
\text { clearly }\end{array}$ & 4.43 & .739 & 4 & 4.12 & .803 & 5 \\
\hline 7 & 12. Have English pronunciation close to natives & 4.11 & .832 & 7 & 4.12 & .776 & 5 \\
\hline 8 & $\begin{array}{l}\text { 13. Have high level of English proficiency } \\
\text { (listening, speaking, reading, and writing) }\end{array}$ & 4.43 & .608 & 4 & 4.24 & .750 & 1 \\
\hline 10 & Provide information on the target language culture & 4.40 & .604 & 5 & 4.07 & .730 & 7 \\
\hline 14 & Be able to answer complex questions & 4.23 & .770 & 6 & 4.09 & .750 & 6 \\
\hline
\end{tabular}

Table 7. Mean scores and standard deviations for organization and preparation items

\begin{tabular}{|c|c|c|c|c|c|c|c|c|c|c|}
\hline \multirow[t]{2}{*}{ No. } & \multirow[t]{2}{*}{ Statements } & & & & \multicolumn{3}{|c|}{ Teachers } & \multicolumn{3}{|c|}{ Students } \\
\hline & & & & & Mean & SD & Rank & Mean & SD & Rank \\
\hline \multicolumn{11}{|c|}{ Effective teachers should } \\
\hline 1 & Prepare the lessons well & & & & 4.74 & .443 & 1 & 4.26 & .593 & 1 \\
\hline 2 & $\begin{array}{l}\text { 14. Manage class } \\
\text { systematically }\end{array}$ & time & effectively & and & 4.57 & .558 & 2 & 4.19 & .647 & 2 \\
\hline
\end{tabular}

\subsubsection{Qualitative Data -Teachers' Views}

From the extra comments and suggestions made by the 25 teachers, only three of the five categories proposed by Faranda and Clarke (2004), i.e. rapports, knowledge and credibility, and organization and preparation, were mentioned (see Appendix A: The extra attributes of effective language teachers). In general, teachers should understand the learners' learning styles individually and have their own faith in enhancing the learners' language proficiency. Moreover, teachers should be fair, generous, helpful, and reliable. Using teaching psychology to motivate the learners and having up-to-date information and being connected with the learning content were also important. In conclusion, the extra attributes of effective teachers mostly concentrated on how to have a good 
relationship with the students.

\subsubsection{Qualitative Data -Students' Views}

From the extra views on effective teachers made by 229 of the 613 students, the ranking according to the number of times or frequency of students' suggestions was as follows : (1) rapport: 147 of 229 students $=64.1 \%$ ), (2) delivery: 110 students of 229 students $=48.0 \%$ ), (3) knowledge and credibility: 76 of 229 students $=33.2 \%$ ), (4) organization and preparation: 34 of 229 students $=14.8 \%$ ), and (5) fairness: 13 of 229 students $=5.7 \%$ ).

The students' extra views on effective teachers are summarized in Appendix B. In general, the favorable characteristics of teachers were being fun, fair, patient, cheerful, generous, flexible, friendly, open-minded, energetic, and helpful. The information gathered using the open-ended format correlated with the mean scores shown in Table 2. That is, the students viewed the rapport category (i.e. relationship between teachers and students) as the most important attribute of effective teachers.

\subsection{The Attributes of Effective English Language Learners as Perceived by Teachers and Students}

The quantitatively and qualitatively analyses consisted of two parts: teachers' views and students' views.

\subsubsection{Quantitative Data-Teachers' Views}

As shown in Table 8, the top three attributes of effective language students included having responsibility for learning $(\mathrm{M}=4.86)$, demonstrating effort persistently $(\mathrm{M}=4.71)$, and being enthusiastic and interested in obtaining new knowledge both in and outside the classroom $(\mathrm{M}=4.69)$. Discipline in completing all assigned reading before the class was nominated as the least important $(\mathrm{M}=4.20)$.

Table 8. Mean scores and standard deviation of the attributes of effective English language learners as perceived by the EFL teachers and EFL students

\begin{tabular}{|c|c|c|c|c|c|c|c|}
\hline \multirow[t]{2}{*}{ No. } & \multirow[t]{2}{*}{ Statements } & \multicolumn{3}{|c|}{ Teachers } & \multicolumn{3}{|c|}{ Students } \\
\hline & & Mean & SD & Rank & Mean & SD & Rank \\
\hline \multicolumn{8}{|c|}{ Effective learners should } \\
\hline 1 & $\begin{array}{l}\text { Discipline himself/herself and complete all assigned } \\
\text { reading before class }\end{array}$ & 4.20 & .797 & 12 & 4.17 & .650 & 10 \\
\hline 2 & $\begin{array}{l}\text { Respect classroom or institute' agreements, discipline, and } \\
\text { regulations }\end{array}$ & 4.40 & .497 & 10 & 4.20 & .637 & 9 \\
\hline 3 & Apply effort persistently & 4.71 & .462 & 2 & 4.28 & .641 & 5 \\
\hline 4 & $\begin{array}{l}\text { Be enthusiastic about and interested in obtaining new } \\
\text { knowledge both in and outside the classroom }\end{array}$ & 4.69 & .471 & 3 & 4.23 & 672 & 7 \\
\hline 5 & Have responsibly for learning & 4.86 & .355 & 1 & 4.34 & .621 & 3 \\
\hline 6 & $\begin{array}{l}\text { Have the courage to ask, share opinions, and try to find } \\
\text { solutions by trial and error }\end{array}$ & 4.51 & .562 & 8 & 4.22 & .716 & 8 \\
\hline 7 & Practice and review learning content regularly & 4.55 & .564 & 6 & 4.17 & .740 & 10 \\
\hline 8 & $\begin{array}{l}\text { Manage learning effectively, be able to set priorities, and } \\
\text { organize learning content systematically }\end{array}$ & 4.34 & .684 & 11 & 4.16 & .665 & 11 \\
\hline 9 & $\begin{array}{l}\text { Try to find learning strategies to practice and improve the } \\
\text { four language skills (reading, listening, writing, speaking), } \\
\text { as well as pronunciation, grammatical rules, and vocabulary }\end{array}$ & 4.64 & .489 & 4 & 4.27 & .684 & 6 \\
\hline 10 & Be able to master shyness or loss of confidence well & 4.54 & .561 & 7 & 4.22 & .728 & 8 \\
\hline 11 & Be honest. Not cheat on the tests or assignments & 4.71 & .519 & 2 & 4.27 & .713 & 6 \\
\hline 12 & Be polite and respect the teachers & 4.43 & 608 & 9 & 4.46 & .626 & 1 \\
\hline 13 & Be punctual & 4.63 & .547 & 5 & 4.33 & .661 & 4 \\
\hline 14 & $\begin{array}{l}\text { Understand one's own choice of suitable learning styles } \\
\text { such as collaborative learning, games, visual/audio learning } \\
\text { style }\end{array}$ & 4.43 & .655 & 9 & 4.42 & .633 & 2 \\
\hline
\end{tabular}




\subsubsection{Quantitative Data -Students' Views}

As shown in Table 8 , the highest mean for the attributes of effective language students was being polite and respecting the teacher $(\mathrm{M}=4.46)$, followed by understanding one's own choice of suitable learning styles ( $\mathrm{M}$ $=4.42)$, and being responsible for learning $(\mathrm{M}=4.34)$. The least important attribute was knowing how to manage learning, setting priorities, and organizing learning content $(\mathrm{M}=4.16)$.

\subsubsection{Qualitative Data - Teachers' Views and Experiences}

Sixteen of 35 teachers suggested extra attributes of effective learners (Appendix A), where learning motivation and objectives were demanded for a good learner (i.e. teachers 1, 5, 9, 14, 21, 28, 30, 33, 35), while being enthusiastic (i.e. teachers $4,6,21,24,31$ ) and having moral shame and dread were highly recommended (i.e. teachers 1, 2, 21, 27, 35). Polite manners were required for effective students (i.e. teachers 3, 5, 12). Teacher 32 and 34 suggested that being good students they should practice their language ability regularly.

Moreover, the teachers were requested to narrate both pleasant and unpleasant experiences of language teaching (Appendix C). Pleasant experiences included the students' putting effort persistently into learning despite their low language proficiency, attending class regularly, and realizing the importance of English.

Unpleasant students' behaviors included students' being lazy, forgetting to bring their textbook, playing games, chatting via social media, sleeping in the classroom, lack of English background knowledge with huge language proficiency gaps among students in one class, lack of opportunities to practice the target language, feeling too embarrassed to practice English in the classroom, and cheating during examinations or copying their friends' assignments and homework.

\subsection{The Main Obstacles to English Teaching and Learning in the Thai Context as Perceived by Students}

The findings are presented in two sections: teachers' views and students' views.

\subsubsection{Teachers' Views on the Obstacles to English Teaching Process}

The obstacles to the English teaching process were grouped as follows: (1) teachers, (2) classroom management, (3) authority, and (4) technology issues.

To begin with, teachers have a lot of duties, including teaching, doing research and administrative tasks, being part of committees to approve research proposals, and so on. Some teachers have insufficient English language skills and lack the cultural knowledge of a target language. Moreover, there are usually more than forty students in a classroom, making it difficult to manage classroom effectively. Even though the university authorities realize the importance of English, they do not provide adequate financial support as there are important issues to deal with. Regarding the technology issues, there are no audio or visual aids, nor Internet access in the classroom. Some classes have audio and visual aids, but they are broken and there are no technicians to help the teachers that have no technical knowledge.

\subsubsection{Students' Views on the Obstacles to the English Learning Process}

The students were asked to rank the obstacles to their language learning. Among the 10 statements as shown in Table 9, the top obstacles to the students' language learning were the difficult and complicated learning content of English, with many words and rules that were difficult to remember, as well as embarrassment when making mistakes. One hundred fifty-nine students $(25.9 \%)$ ranked the difficult content as the most important obstacle, while 450 students $(73.4 \%)$ ranked it as the second most important factor. Eighty-five students $(13.9 \%)$ ranked the complicated content as the third most important. Another obstacle reported by 72 students $(11.7 \%)$ was that they felt embarrassed making mistakes.

Overall, the frequency distribution (Table 9) on the obstacles to English learning suggested that students believed that English is a difficult subject (i.e. item 1), with complicated learning content (i.e. item 6). More importantly, the students had no content knowledge (i.e. item 2) and felt embarrassed when making mistakes (i.e. item 5).

Regarding the students' contentment with learning English with native Thai and native English teachers, 514 students (83.8\%) preferred native Thai teachers, whereas 99 students preferred native English teachers. More than fifty percent of the respondents explained that their reason for choosing native Thai teachers was that they could ask questions whenever they did not understand the content. Moreover, Thai teachers have experienced difficulties in learning English so they would know how to transfer knowledge effectively (i.e.56 of 514 students) and how to motivate the students (i.e.114 of 514 students). Some said that native Thai teachers prepared for the 
lessons better (i.e. 46 of 514 students). In all, the students thought that native Thai teachers might have the necessary language proficiency, teaching technique, and strategies necessary to teach the target language (i.e. 65 of 514 students). It was even asserted that some native Thai teachers could teach better than native English speakers (i.e. 31 students), as some native English speakers have only language skills but lack teaching skills and teaching psychology (i.e. 22 of 517 students) and do not understand the nature of Thai students (i.e.13 of 517 students). Eleven students complained that if they could not understand what native Thai teachers were teaching, it would be very difficult to understand native speakers, while 3 students believed that the best way to learn English was by paying expensive fees to tutors outside the university.

However, some students viewed that Thai accents were the main problems in learning with native Thai teachers (i.e. 23 of 99 students preferred native speaking teachers). These students loved to study with native English speakers since they could learn to pronounce the target language close to the way a native does. Five students believed that native English teachers could explain grammatical structures more clearly. Nine students did not mind learning with native or non-native English speakers as long as the teachers had the ability to transfer knowledge.

Table 9. Frequency and percent of the causes obstructing English learning as perceived by students

\begin{tabular}{|c|c|c|c|c|c|c|c|c|}
\hline \multirow[b]{2}{*}{ No. } & \multirow[b]{2}{*}{ Statement } & \multirow{2}{*}{$\begin{array}{l}\text { No. } \\
\text { of } \\
\text { students }\end{array}$} & \multicolumn{2}{|l|}{ Rank 1} & \multicolumn{2}{|l|}{ Rank 2} & \multicolumn{2}{|l|}{ Rank 3} \\
\hline & & & Frequency & $\%$ & Frequency & $\%$ & Frequency & $\%$ \\
\hline 1 & $\begin{array}{l}\text { I think that English is difficult to } \\
\text { learn. }\end{array}$ & 613 & $159^{*}$ & 25.9 & $450^{*}$ & 73.4 & 4 & 0.7 \\
\hline 2 & $\begin{array}{l}\text { I have no English knowledge or I } \\
\text { do not know English since I don't } \\
\text { understand what the teachers taught } \\
\text { in primary school or secondary } \\
\text { school. }\end{array}$ & 194 & 71 & 11.6 & 59 & 9.6 & 64 & $\begin{array}{l}10 . \\
4\end{array}$ \\
\hline 3 & $\begin{array}{l}\text { I have had terrible experience with } \\
\text { this subject. }\end{array}$ & 81 & 20 & 3.3 & 34 & 5.5 & 27 & 4.4 \\
\hline 4 & $\begin{array}{l}\text { I think English is not useful since I } \\
\text { do not use it in my everyday life. }\end{array}$ & 68 & 19 & 3.1 & 24 & 3.9 & 25 & 4.1 \\
\hline 5 & I feel embarrassed about mistakes. & 168 & 32 & 5.2 & 64 & 10.4 & $72 *$ & $\begin{array}{l}11 . \\
7\end{array}$ \\
\hline 6 & $\begin{array}{l}\text { I think English is very complicated } \\
\text { because of many words and rules. I } \\
\text { cannot remember all of the words } \\
\text { and rules. }\end{array}$ & 247 & 70 & 11.4 & 85 & 13.9 & 92 & $\begin{array}{l}15 . \\
0\end{array}$ \\
\hline 7 & I do not like English. & 57 & 13 & 2.1 & 20 & 3.3 & 24 & 3.9 \\
\hline 8 & $\begin{array}{l}\text { There are too many people in a } \\
\text { classroom. }\end{array}$ & 71 & 14 & 2.3 & 26 & 4.2 & 31 & 5.1 \\
\hline 9 & $\begin{array}{l}\text { I have to learn with strict } \\
\text { teacher/ineffective and boring } \\
\text { teaching style. I hate English. When } \\
\text { I have to attend the class, it is living } \\
\text { in a hell. }\end{array}$ & 75 & 22 & 3.6 & 23 & 3.8 & 30 & 4.9 \\
\hline 10 & $\begin{array}{l}\text { I think learning English is very } \\
\text { boring. }\end{array}$ & 49 & 10 & 1.6 & 17 & 2.8 & 22 & 3.6 \\
\hline
\end{tabular}

\section{Discussion}

This study aimed at investigating the teachers' and students' viewpoints regarding the characteristics of effective English language teachers and learners, as well as finding the main obstacles to language learning in the Thai 
context as perceived by teachers and students. The discussion of the findings is divided into three parts according to the research questions.

\subsection{The Attributes of Effective English Language Teachers as Perceived by EFL Teachers and EFL Students}

Overall, the findings clearly confirmed that EFL teachers and learners have different perspectives. The teachers gave more weight to the items related to preparing and providing a comprehensive syllabus with proper learning content and methodology, whereas the students focused more on items relating to the teachers' having positive attitudes towards them.

When closely investigated by attribute, the findings indicated that "being fair in providing feedback, grading, and paying attention to individual differences" was the most important attribute. At the same time, the knowledge of how to teach effectively such as guiding students, providing them with a relaxed environment, having the ability to organize, explain, and clarify the learning content, were important as well. Extra comments and suggestions by the teachers suggested that having a good relationship with students (i.e. rapport) was essential for building a relaxed atmosphere.

In conclusion, the findings for both the quantitative and quantitative analyses suggested that the teachers defined effective EFL teachers as those with good preparation, fairness, good communication skills, and good relations with and understanding of the students. When examined closely by attribute, effective teachers were expected to understand the course content, objectives and evaluation, prepare lessons by using relevant real word examples, and be patient.

There are very few studies on effective teachers as perceived by teachers in the Thai context. Most research focuses on effective teachers as perceived by the students (Babai and Sadeghi, 2009; Barnes and Lock, 2010, 2013; Chen and Lin, 2009; Faranda and Clarke, 2004; Hajizadeh and Salahshour, 2014; Park and Lee, 2006; Rammal, 2006; Ramsden, 2003; Xiao, 2006; Wichadee, 2010). Thus, this study can be viewed as a new conceptualization of the issue of attributes of effective teachers as perceived by the EFL university teachers in the Thai context.

However, from the students' viewpoint, the relationship between teachers and students (i.e. rapport) was the most important attribute; in particular, the students would like the teachers to have positive attitudes towards them and be helpful both in and outside the classroom. In other words, for the students, effective teachers should listen to them and make themselves accessible for consultation. The qualitative information also confirmed the preferred characteristics of teachers as perceived by students - that the teachers should be fun, fair, patient, cheerful, generous, flexible, friendly, open-minded, and energetic. These findings are in line with the Thai character of wanting to have fun and being fond of pleasure (Fry, 2002; Nguyen, n.d.). However, creating enjoyable activities in the classroom is not easy. There are challenges involved (Okan, 2003), as teachers have to design the activities in a meaningful manner so that students will have sufficient language proficiency level for them (Nguyen and Thi Khuat, 2003).

The students also believed that effective teachers should have subject-matter knowledge and the ability to present or transfer the knowledge. The findings of this study were consistent with those of Wichadee (2010), Branes and Lock (2013), Chen (2012) in that rapport or the personal characteristics of teachers were the most important attribute perceived by students. When closely examined by attribute, these findings are in substantial agreement with those of Faranda and Clark (2004), Park and Lee (2006), Rammal (2006), Xiao (2006) in that effective teachers should have positive attitudes towards students (Faranda and Clark, 2004; Park and Lee, 2006; Rammal, 2006) provide fun activities (Biyaem, 1997; Chanseawrassamee, 2012; Fry, 2003; Nguyen, n.d.; Young, 2013), be proficient in English (Park and Lee, 2006; Rammal, 2006), and prepare the lessons well (Park and Lee, 2006).

\subsection{The Attributes of Effective English Language Learners as Perceived by EFL Teachers and EFL Students}

Both teachers and students agreed that students should be responsible for their learning (with a mean score of 4.86 (teachers) and 4.34 (students). The teachers sited this attribute as the first priority, while students gave it the third ranking. These findings are in line with those of Biyaem (1997) and Foley (2005), which indicated that students in Thailand lack responsibility for their own learning. Extra comments by the teachers suggested that students are lazy, forget to bring their textbook, chat and sleep in the classroom, and most importantly, students feel embarrassed practicing English and usually cheat on the examination or copy their friends' homework. Fear of making errors and losing face is one of the cultural factors that obstruct the process of transferring knowledge in 
Thailand (Biyaem, 1997).

What is more interesting, the students suggested that good teachers should not give any assignments (Table 1). This implies that the students seemed to be very lazy and they liked to sit and do nothing in the classroom and out of the classroom they enjoyed their life. In addition, the students rated the ability to manage learning effectively, set priorities, organize their target language learning, as well as discipline themselves and complete all assigned reading before class as the least important attributes for effective learners. These findings reflect the problems of English teaching and learning in the Thai context. Such problems are difficult to solve since particular attributes are required from learners.

However, when investigating the information on pleasant teaching experiences, the study found that some students put persistent efforts into English learning despite their low language proficiency and that the students realized the importance of English. Moreover, some students had their own motivation and were enthusiastic about learning the target language, attended class regularly, participated in all of the activities, and helped one another to complete the assignments.

\subsection{The Main Obstacles to Language Learning in the Thai Context as Perceived by Teachers and Students}

The main obstacles to language learning can be grouped into four categories as follows:

\subsubsection{Obstacles to English Teaching and Learning Involving Teachers}

Having a heavy teaching load and insufficient language ability were considered as the main obstacles to English teaching and learning in the Thai context. Lack of native English teachers (Biyaem, 1997; Fry, 2003; Nguyen, n.d.; Noom-ura, 2013; Young, 2013) was not a problem for this study since the findings indicated that the students preferred native Thai teachers.

\subsubsection{Obstacles to English Teaching and Learning Involving Students}

The students reported two main obstacles; namely, feeling embarrassed when making mistakes and having no content knowledge. When combined with the comments on unpleasant teaching experiences, the obstacles to English teaching and learning involving students can be summarized as follows: (1) students have insufficient knowledge and skills, (2) they lack confidence in target language communication, (3) they have no background target knowledge, (4) they feel embarrassed practicing English, and (5) they lack opportunities to practice the target language.

\subsubsection{Obstacles to English Teaching and Learning Involving Learning Content}

The findings indicated that students viewed the English learning content as very difficult. Complicated learning content with a lot of grammatical rules and words made them stressed.

\subsubsection{Obstacles to English Teaching and Learning Involving Other Factors}

Inadequate supply of computers, technological aids and technicians, and too many students in a classroom were other obstacles to teaching and learning English in the Thai context.

The findings of this study are in substantial agreement with those of Biyaem (1997), Dhanasobhon (2006), Kaewmorakot (2005), Noom-ura (2013), and Silapasatham (2007) in that there were obstacles to English learning on the part of both teachers and learners. Specifically, Thai teachers usually have heavy teaching loads and insufficient English language skills and there are too many students in a class, while the classrooms are inadequately equipped with educational technology. Meanwhile, Thai learners are not responsible for their own learning; they lack the opportunity to use English in their daily lives and do not have confidence in communicating or are too shy to speak in English.

\section{Conclusion and Recommendations}

This study investigated the characteristics of effective English teachers as perceived by teachers and students, and surveyed the problems obstructing English language teaching and learning in Thailand. Overall, teaching preparation and the use of effective teaching methodology, together with being patient, not insulting the students, and giving clear advice, were positioned as the most import attributes. The students gave more weight to the ways in which teachers behaved toward them (i.e. rapport), for example, having a positive attitude towards them, being helpful, generous and caring about them, as well as preparing lessons well with fun activities. In other words, the results suggested ways to effectively encourage students to learn the target language and to improve pedagogical strategies by creating a safe and stimulating environment, either by means of improving the teaching 
methods or having good relationship with students.

One way to encourage more active participation of students is to design fun and meaningful activities in the learning process (e.g. a classroom). As Thai students like fun activities, the more relaxed environment could help enhance their learning engagement as well as lessen their fear of making mistakes or losing face. Thus, it is very important that teachers be trained or have knowledge of pedagogical strategies that enhance the students' motivation. For example, teachers could keep a record of their pedagogical strategies or techniques that worked effectively as an instructional manual of academic resources. Building teaching communities where teachers can share their pleasant and unpleasant experiences of language teaching and problem solving could also be very useful.

Moreover, as the study results revealed that Thai students lack responsibility for their own, collaborative learning projects with clear roles or responsibilities could help solve this problem. As Thais usually look up to their referent social groups or need to be respected by the group, through collaborative techniques, students could construct their own knowledge by themselves, thereby improving their leadership, management, interpersonal skills. In order to deal with students that believe that English is a difficult subject, teachers could design activities that are based on the students' interests and language proficiency (i.e. not too easy or too difficult).

From a larger perspective, university authorities and language teachers could create an English Zone in particular areas (e.g. classroom, cafeteria) so as to encourage students to speak the target language more. The English curriculum could also be improved according to labor demands as well as the students' interests. For example, since most KMUTNB students are engineering students, an English curriculum should be geared more towards technical English.

It is also important to acknowledge the limitations of this study, and to be careful when generalizing the findings. First, not all of the participants were interviewed, as the information from the questionnaire was considered sufficient to answer the research questions. However, if other researchers would like to recheck the findings or gather more in-depth information, the interview approach could be expanded. Secondly, although the study's sample of 35 language teachers and 613 engineering students at KMUTNB is not representative of university teachers and students, this study was the first to investigate the views of both teachers and students on the characteristics of effective teachers and students in the Thai context. The researcher hopes that in the future other researchers will investigate the characteristics of effective teachers and learners on a larger scale or with different groups of learners as well as examine on a correlation between the students' achievement and the attributes of EFL teachers.

\section{References}

Babai, H., \& Sadeghi, K. (2009). Characteristics of effective English language teachers as perceived by Iranian teachers and learners of English. English Language Teaching, 2(4), 130-143.

Barnes, B. D., \& Lock, G. (2010). The attributes of effective lecturers of English as perceived by students in a Korean university. Australian Journal of Teacher Education, 35(1), 139-152. http://dx.doi.org/10.14221/ajte.2010v35n1.2

Barnes, B. D., \& Lock, G. (2013). Student perceptions of effective foreign language teachers: A quantitative investigation from a Korean university. Australian Journal of Teacher Education, 38(2), 19-36. http://dx.doi.org/10.14221/ajte.2013v38n2.2

Biyaem, S. (1997). Learner Training: Changing Roles for a Changing World, Educational Innovation for Sustainable Development. $3^{\text {rd }}$ UNESCO-ACEID International Conference, Bangkok.

Bolton, K. (2008). English in Asia, Asian Englishes, and the issue of proficiency. English Today, 24(2), 3-12. http://dx.doi.org/10.1017/S026607840800014X

Brown, H. D. (2000). Principles of Language Learning and Teaching. Englewood Cliffs, NJ: Prentice Hall Regents. Upper Saddle River, New Jersey.

Chanseawrassamee, S. (2012). Teaching adults learners English through a variety of activities: Perception on games and rewards, US-China Foreign Language, 10(7), 1355-1374.

Chen, J. (2012). Favorable and unfavorable characteristics of EFL teachers perceived by university students of Thailand. International Journal of English Linguistics, 2(1), 213-219. http://dx.doi.org/10.5539/ijel.v2n1p213 
Chen, Y. J., \& Lin, S. C. (2009). Exploring characteristics for effective EFL teachers from the perceptions of junior high school students in Tainan. STUT Journal of Humanities and Social Sciences, 2,219-249.

Dhanasobhon, S. (2006). English language teaching dilemma in Thailand.

Diamond, R. M. (1998). Designing and assessing courses and curricula: A practical guide (Rev. ed.). San Francisco: Jossey-Bass.

Ehrman, M., Leaver, B. L., \& Oxford, R. L. (2003). A brief overview of individual differences in second language learning. System, 31, 313-330. http://dx.doi.org/10.1016/S0346-251X(03)00045-9

Faranda, W. T., \& Clarke, I. (2004). Students' observation of outstanding teaching: Implications for marketing educators. Journal of Marketing Education, 23(2), 271-281. http://dx.doi.org/10.1177/0273475304268782

Foley, J. (2005). English in Thailand. RELC, 36(2), 223-234. http://dx.doi.org/10.1177/0033688205055578

Fry, F. W. (2002, September 2-5). The evolution of educational reform in Thailand. Paper presented at the Second International Forum.

Gardner, R. C., Day, J. B., \& MacIntyre, P. D. (1992). Integrative motivation induced anxiety and language learning in a controlled environment. Studies in Second Language Acquisition, 14, 197-214. http://dx.doi.org/10.1017/S0272263100010822

Ghasemi, B., \& Hashemi, M. (2011). The study of the characteristics of successful English language teachers from the view point of the English language students of Islamic Azad University, Hamedan Branch, in Procedia-Social and Behavioral Sciences, 28, 411-415.

Hajizadeh, N., \& Salahshour, N. (2014). Characteristics of effective EFL instructors: Language teachers' perceptions versus learners' perceptions. International Journal of Applied Linguistics and English Literature, 3(1), 202-214. http://dx.doi.org/10.7575/aiac.ijalel.v.3n.1p.202

Kaewmorakot, C. (2005, August 28). English Teaching: Complete overhaul 'essential'. The Nation 8.

Khamkhien, A. (2010). Teaching English speaking and English speaking tests in the Thai context: A Reflection from Thai perspective. English Language Teaching, 3(1), 184-190.

Lowman, J. (1997). Teaching concern. Newsletter of the Teaching Resource Center for Faculty and Teaching Assistants, 21, 22-27.

Murray, H. G. (1991). A time for local perspectives. In J. Murphy, \& P. Byrd (Eds.), Understanding the course we teach: Local perspectives on English language teaching (pp. 3-10). Ann Arbor: University of Michigan Press

Nguyen, T .H. (nd). Thailand: Cultural background for ESL/EFL teachers.

Nguyen, T. H., \& Thi Khuat, K. (2003). The effectiveness of learning vocabulary through games.

Noom-ura, S. (2013). English-teaching problems in Thailand and Thai teachers' professional development needs. English Language Teaching, 6(11), 139-147. http://dx.doi.org/10.5539/elt.v6n11p139

Norton, B., \& Toohey, K. (2001) Changing perspectives on good language learners. TESOL Quarterly, 35(2), 307-322. http://dx.doi.org/10.2307/3587650

Nunan, D. (1999). Second Language Teaching and Learning. Boston, Heinle and Heinle.

O’Maley, J. M., \& Chamot, A. U. (1990). Learning strategies in second language acquisition. Cambridge: Cambridge University Press. http://dx.doi.org/10.1017/CBO9781139524490

Okan, Z. (2003). Edutainment: is learning at risk? British Journal of Educational Technology, 3(34), 255-264. http://dx.doi.org/10.1111/1467-8535.00325

ONEC. (2003). Education in Thailand 2002/2003. Bangkok: ONEC Publication

Oxford, R. L. (1989). Use of language learning strategies: A synthesis of studies with implications for strategy training. System, 17, 235-247. http://dx.doi.org/10.1016/0346-251X(89)90036-5

Oxford, R. L. (1990). Language Learning Strategies: What Every Teacher Should Know. New York: Newbury House.

Pande, V. B. (2013). Problems and remedies of teaching English as second language. Confluence (22-23 February), 416-420. 
Park, G. P., \& Lee, H. W. (2006). The characteristics of effective English teachers as perceived by high school teachers and students in Korea. Asia Pacific Education Review, 7(2), 236-248. http://dx.doi.org/10.1007/BF03031547

Phothongsunan, S. (2014). Investigating Thai university students' attributions of English learning success: an international university context. In the 2014 WEI International Academic Conference Proceedings Vienna, Austria.

Prabhu, N. S. (1990). There is no best method-Why? TESOL Quarterly, 24, 232-338. http://dx.doi.org/10.2307/3586897

Rammal, S. M. (2006). The other side of the mirror: ESL students offer their opinions of good language teaching. Retrieved from: http://www.usingenglish.com/articles/other-side-mirror.html

Ramsden, P. (1992). Learning to Teach in Higher Education. London: Routledge. http://dx.doi.org/10.4324/9780203413937

Ramsden, P. (2003). Learning to Teach in Higher Education. $2^{\text {nd }}$ Edition. London: Routledge.

Reid, J. M. (1987). The learning style preferences of ESL students. TESOL Quarterly, 21, 87-111. http://dx.doi.org/10.2307/3586356

Rubin, J. (1975). What the "good language learner" can teach us. TESOL Quarterly, 9(1), 41-51. http://dx.doi.org/10.2307/3586011

Silapasatham, S. (2007). Knowledge and competency development of Thai teachers teaching English in primary schools.

Skehan, P. (1989). Individual Differences in Second Language Learning. London: Edward.

Ushida, E. (2005).The Role of Students' Attitudes and Motivation in Second Language Learning in Online Language Courses. CALICO Journal, 23(1), 49-78.

Wichadee, S. (2010). Defining the effective English language teacher: Students' and teachers' perspectives. In A. M. Stoke (Ed.), JALT 2009 Conference Proceedings. Tokyo: JALT.

Xiao, L. (2006). Bridging the gap between teaching styles and learning styles: A crosscultural perspective. TESL-EJ, 10(3).

Xuerong, F. (2012). Excellent English teacher's classroom strategies: a case study of three college English teachers in China. Higher Education of Social Science, 2(1), 17.

Young, D. (2013). Perspectives on cheating at a Thai University. Language Testing in Asia, 3, 6. http://dx.doi.org/10.1186/2229-0443-3-6

Young, D. J., \& Oxford, R. L. (1997). A gender-related analysis of strategies used to process written input in the native language and a foreign language. Applied Language Learning, 8(1), 43-73. 


\section{Appendix A}

Extra attributes of effective teachers as suggested by the teachers

\begin{tabular}{|c|c|}
\hline Categories & Suggestions \& Comments \\
\hline 1.Rapport & $\begin{array}{l}\text { Effective teachers should } \\
\text { - understand the learners' learning styles individually. (i.e. Teachers } 3,15 \text {, } \\
23,33,35 \text { ) } \\
\text { - have faith in their careers. (i.e. Teachers } 7,19,26,27 \text { ) } \\
\text { - devote himself/herself to solving learning and teaching problems. (i.e. } \\
\text { Teachers } 2,26,27 \text { ) } \\
\text { - have teaching ethics. (i.e. Teacher 5) } \\
\text { - have positive response to the students' assignments. (i.e. Teachers } 17,23 \text { ) } \\
\text { - create positive and collaborative atmosphere as much as possible. (i.e. } \\
\text { Teacher } 17 \text { ) } \\
\text { - be a good communicator. (i.e. Teacher } 29 \text { ) } \\
\text { - be fair, generous, helpful, sacrifice and reliable. They should apply teaching } \\
\text { psychology to motivate their students (i.e. Teachers } 8,14,19,31 \text { ) } \\
\text { - be able to connect learning content to everyday life. (i.e. Teachers } 5,7,14 \text { ) } \\
\text { - be an up-to-date person. (i.e. Teachers } 15,20,25,27 \text { ) }\end{array}$ \\
\hline 2.Knowledge and credibility & $\begin{array}{l}\text { Effective teachers should } \\
\text { - link the learning content to real life and teach beyond the textbook. (i.e. } \\
\text { Teacher 16) } \\
\text { - have ability to explain the content understandably. (i.e. Teachers } 8,10 \text { ) } \\
\text { - have ability to transfer knowledge. (i.e. Teacher } 25 \text { ) } \\
\text { - understand the contents. (i.e. Teachers } 16,20,35 \text { ) } \\
\text { - have native's culture knowledge and experience. (i.e. Teacher } 23 \text { ) }\end{array}$ \\
\hline 3.Organization and preparation & $\begin{array}{l}\text { Effective teachers should } \\
\text {-prepare well and be organized. (i.e. Teachers 5, 20) } \\
\text {-provide all materials and supplemental materials. (i.e. Teacher 20) }\end{array}$ \\
\hline
\end{tabular}

\section{Appendix B}

Extra attributes of effective teachers suggested by the students

\begin{tabular}{cll}
\hline Rank & Categories & Suggestions \& Comments \\
\hline 1 & Rapport & Effective teachers should \\
& - be fun, fair, patient, cheerful, generous, flexible, friendly, and \\
& open-minded \\
& - care about the students \\
& - listen to students \\
& - not be a strict teacher and not be serious or get angry easily \\
& - not insult or look down on the students \\
& - be an excellent communicator \\
& - understand the learners' differences such as learning styles, educational \\
& background, and language proficiency \\
& - find excellent ways to create the learners' motivation. \\
& - be beautiful, sexy, and pretty or have good personality. \\
& Effective teachers should \\
& - teach with interesting teaching methods, especially games. \\
& - make difficult content easy by using easy words. \\
& - correct errors, give related examples, provide opportunity for students \\
& to practice the target language. \\
& - talk slowly and use teaching aids and media. \\
& - tailor the content to the level of the learners' proficiency. \\
& - answer questions and assess the students' comprehension. \\
& - not speak only English in the classroom. They should speak Thai when \\
& the learning content needs to be explained. \\
&
\end{tabular}


Appendix B (cont.)

Extra attributes of effective teachers suggested by the students

\begin{tabular}{cll}
\hline Rank & Categories & Suggestions \& Comments \\
\hline 3 & Knowledge and credibility & Effective teachers should \\
& & - link the learning content to real life. \\
& - understand content well and use simple explanations. \\
& & - know how to transfer knowledge. \\
& & - pronounce close to natives. \\
& & - have target language culture knowledge and experience. \\
& & Effective teachers should \\
4 & Organization and & - prepare well and be organized. \\
& preparation & - provide all materials and supplemental materials. \\
5 & Fairness & Effective teachers should \\
& & - treat all students equally. \\
& & - provide homework and assignments. \\
& & - be fair with grading. \\
\hline
\end{tabular}

\section{Appendix C}

Pleasant and unpleasant experience with language teaching narrated by the teachers

\begin{tabular}{cl}
\hline $\begin{array}{c}\text { Teacher } \\
\text { No. }\end{array}$ & Pleasant Experience \\
\hline 2 & $\begin{array}{l}\text { The students asked questions when they did } \\
\text { not understand the learning content. They } \\
\text { attended class regularly and they } \\
\text { recognized the importance of English. }\end{array}$ \\
6 & $\begin{array}{l}\text { The students were really enthusiastic about } \\
\text { learning English since they would like to } \\
\text { travel around the world. They mentioned } \\
\text { that English is a common medium of } \\
\text { communication. } \\
\text { The students realized the important roles of } \\
\text { English so they had high motivation to } \\
\text { learn. They attended class regularly. }\end{array}$
\end{tabular}

15 The students paid attention to the lessons and tried to help each other to reach learning goals.

Unpleasant Experience

Some students chatted with each other. Some read cartoons and accessed social media. They had negative attitudes toward English. There was a large gap of language proficiency among students in the classroom. Some students were very lazy. They did nothing in the class. Some felt embarrassed to speak in front of the class and tried to not participate in any activities. They had no discipline to learn the target language. They wanted high scores but tried less.

They had no content knowledge. Even though they worked very hard, they sometimes got impatient. They paid attention only to their major subject such as engineering. They had no motivation to learn. Some students had private life problems.

They forgot to bring learning materials such as books or sheets to the class. They came to class late.

21 The students applied effort persistently. They prepared for target language learning. They attended class regularly and participated in all activities.

25 The students attended class regularly and participated in all activities. They worked very hard to improve their language proficiency.

31 The students respected the teacher. They attended class regularly and participated in all activities. They had high responsibility for studying.

Some students slept in the classroom. Some did not do any assignments or homework. They enjoyed life outside of the classroom. They were very lazy and had no responsibility.

It was very difficult to teach since there was a combination of students ranking from very high to very low language proficiency. Students lacked the motivation to learn.

Some put their effort into winning the online games while studying in the classroom. They really loved to learn in a relaxed environment. Teachers should not give any assignments but students should get better grades. It was difficult to manage or create activities since they had different language proficiency. 


\section{Appendix C (cont.)}

Pleasant and unpleasant experience with language teaching narrated by the teachers

\begin{tabular}{lll}
\hline $\begin{array}{l}\text { Teacher } \\
\text { No. }\end{array}$ & Pleasant Experience & Unpleasant Experience \\
\hline 35 & $\begin{array}{l}\text { The students practiced English inside and } \\
\text { outside the classroom. }\end{array}$ & $\begin{array}{l}\text { Some students cheated on the examination and copied } \\
\text { their friends' assignments and homework. They felt } \\
\text { that cheating was a norm in Thai society. They came to } \\
\text { class so late and took a break for a long time. Some had } \\
\text { lunch at 10:30 and returned to study at 11:30. }\end{array}$ \\
\hline
\end{tabular}

\section{Copyrights}

Copyright for this article is retained by the author(s), with first publication rights granted to the journal.

This is an open-access article distributed under the terms and conditions of the Creative Commons Attribution license (http://creativecommons.org/licenses/by/3.0/). 